\author{
Grzegorz Sztabiński \\ Władysław Strzemiński Academy of Fine Arts in Łódź \\ grzegorzsztabinski@op.pl
}

\title{
ART, PARTICIPATION AND AESTHETICS
}

\begin{abstract}
The authors of the principal concepts that combine art with participatory issues use the term "aesthetics" to refer to their theories. The aim of the article is to examine the aspects in which these authors refer to the traditional issues of aesthetics and how they modify them. The discussion focuses on three concepts. In Nicolas Bourriaud's relational aesthetics, the notion of "form", modified in such a way as to include human relations appearing in connection with artistic situations, plays an important role. This way viewers and their behavior become part of the works of art. In the article this issue is confronted with the theory of the Umberto Eco's concept of "open work". Selected works by Rirkrit Tiravanija, Felix Gonazalez-Torres and Liam Gillick are also discussed as examples of relational art. Grant Kester's dialogical aesthetics is presented as an example of the link between art and participation, in which experience is brought to the foreground and ethical values dominate. Claire Bishop, on the other hand, believes that participatory art makes far-reaching changes in the understanding of aesthetics necessary. Referring to Jacques Rancière's philosophical concept, she argues that the inconclusive nature of aesthetic experience entails the necessity of questioning the way in which the world is organized. Therefore, the "sensible sharing" that takes place in participatory art is at the same time a political judgment. Moreover, the English author places emphasis not the harmonization of interpersonal relations (presumed in relational aesthetics), but the antagonism that allows us to constantly redefine and make social problems the subject of debates. The article concludes with a question whether relational, dialogical and participatory aesthetics opens up a new field for aesthetic reflection built over artistic phenomena.
\end{abstract}

Keywords: relational aesthetics, dialogical aesthetics, participatory aesthetics, contemporary aesthetics and reflection on art

It is puzzling that theoretical concepts concerning relational, participatory and dialogical art are described by their authors as aesthetic theories. In all these cases, we are dealing with questioning or radically modifying the concepts that 
have hitherto prevailed in this field of knowledge, while at the same time retaining - generally speaking - terminology used in this field. Words such as "art", "work of art", "form", "creativity", etc. are still used, although the meaning attributed to them changes. Also disappearing is the division into specific media employed in art, which used to be the basis for the classification of fine arts. Moreover, no new intermedia nor multimedia are created, and it is generally assumed that all means can be applied, both those that were once considered as part of one of the artistic fields and those that belong to the sphere of life practice. The division between the artist and the recipient has become blurred. The recipient is actually the participant of the event and its co-creator. Thus, the distinction between roles identified within an aesthetic situation, where the ranges of expectations and rights were separated, is no longer valid. The list of these differences could be expanded with other elements. All of them clearly indicate that the phenomena from the circle of participatory creativity cannot be reduced to traditional scopes of aesthetic concepts. Nor are they their opposites, such as those that appeared in the avant-garde trends, where the notion of "art" was contrasted with "anti-art", "non-art" or "post-art", and the role of the artist was reduced to the concept of a constructor of a new reality, ideologist, tribunus plebis, etc. It is not about negating art or aesthetics, but about staying within it and at the same time radically changing the character and sense of the distinctions it adopts.

The position of relational, participatory or dialogical aesthetics - since such names are used by creators of theories from the circle of concepts discussed here - is therefore unique. In none of these disciplines is noisy negation practiced, typical of the idea of anti-aesthetics proclaimed in the 1960s and 1970s. Thus, manifesto-like poetics is absent from written texts. Discourse of the representatives of the above concepts does not herald a radical change. Reading their writings, one feels that we are firmly within the field described by the very name that defines their concepts, although it turns out that this is a highly transformed aesthetics. Therefore, are we dealing here with a real change in the way of understanding aesthetic issues corresponding to the changes in the way contemporary art operates? All representatives of the concepts discussed here emphasize that the reason for their proposed modifications in the field of aesthetics is to adapt it to the artistic and, more broadly, cultural changes that have taken place for the past thirty years.

Nicolas Bourriaud, who was the first to develop a concept based on a broad participatory approach, is often regarded as an art critic rather than aesthetician. One of the reasons for this is his involvement in artistic life, manifested in his collaboration with artists, organizing exhibitions of art, etc. Writing about the concept of relational aesthetics, Claire Bishop emphasizes that it characterizes "artistic practice of the 1990s" as "an important first step in identifying 


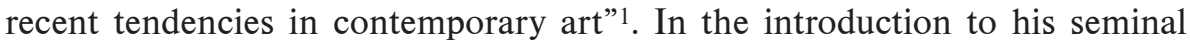
work, Bourriaud also notes that one of the reasons for writing it was the misunderstandings in the art of the 1990s, but immediately follows that statement by pointing out that this was due to "a theoretical discourse complete with its shortcomings" 2 . On the one hand, the author is referring to the discourse of new theories forged by art critics, or those that specify the principles of contemporary art history, while on the other he writes that "art has always been relational in varying degrees, i.e. a factor of sociability and a founding principle of dialogue.", so contemporary artistic activities only revealed what had been an inherent element of art for centuries, and the theory created on this basis addresses general aspects, albeit previously overlooked by aestheticians.

The basic traditional aesthetic concept that the French author tries to equip with a new meaning is "form". As historians emphasize, the term has been used in several different meanings but it has always referred to the characteristics of the work, its properties directly given in a sensory experience, and above all to the arrangement of the parts that constituted the artistic object. Contemplating the arrangement of elements created by the artist was meant to provide the viewer with aesthetic sensations associated with harmony or beauty. In many theories, this division into the actions of the creator and the viewer's behavior was treated as fundamental. Referring to Baumgarten's concept of aesthetics as a "science of perception", theories were formed that presented aesthetic attitude as a passive, selfless perception, in which even the reality of the sensually perceived object does not matter. Bourriaud refers to the traditional meaning of the word "form", defining it as "a coherent unit, a structure (independent entity of inner dependencies) which shows the typical features of a world" ${ }^{3}$ However, in order to explain this, he does not draw on Aristotle (as aestheticians were usually wont to do), but on Lucretius. The reason is probably that the Aristotle's concept of form is static, while in the latter case the formation and decomposition are involved. Citing De rerum natura, the French author writes that according to Epicurus and Lucretius, atoms in void fall parallel, following a diagonal course. If one swerves off, it meets adjacent atoms and then forms are born from the contact between them. They are the result of a meeting of atoms that can freeze, just as ice is said to be frozen water.

I am not going to consider whether this analysis - note bene very brief - is correct. What is important is that a different way of understanding form emer-

1 C. Bishop, Antagonism and Relational Aesthetics, "October", 2004, No 110; reprint: (ed. Z Kocur and S. Leung), Theory in Contemporary Art Since 1985, II ed. Wiley-Blackwell, Malden - Oxford 2013, p. 167.

2 N. Bourriaud, Relational Aesthetics, transl. S. Pleasance and F. Woods, Presses du réel, Paris 2002, p. 18.

3 Ibidem, p. 19. 
ges from it. Unlike in the case of Aristotle, it is not associated with the essence, and its formation is the result of the meeting of atoms, which, while accidental, is then made permanent. Bourriaud sees analogies with art in this respect. He writes: "Lasting encounters, lines and colours inscribed on the surface of a Delacroix painting, the scrap objects that litter Schwitters' "Merz pictures", Chris Burden's performances: over and above the quality of the page layout or the spatial layout, they turn out to be lasting from the moment when their components form a whole whose sense "holds good" at the moment of their birth, stirring up new "possibilities of life". All works, down to the most critical and challenging of projects, passes through this viable world state, because they get elements held apart to meet"4. The cited fragment indicates that the notion of form does not refer here to arrangements of elements that are characterized by permanence, that constitute a unity in a multiplicity, an organic whole, preserving its identity and providing the basis for the aesthetic experiences of viewers. Bourriaud reduces the form to a collection of elements and stresses that it means something different today than it meant in nineteenth century art. $\mathrm{He}$ writes, "Today, the 'glue' is less obvious, as our visual experience has become more complex" 5 . The reason for this complexity are the various types of ingredients from which forms are created in contemporary art, as well as the nature of the arrangements to which this concept can be applied. The French author believes that we have reached the point where we "recognise as a 'world' a collection of disparate element (installation, for instance) that no unifying matter, no bronze, links." 6 . This form is therefore ephemeral in nature and depends to a large extent on the conceptual factors that make it possible to distinguish it. Therefore, it is not so much given as a finite whole with tangible limits (as has been previously assumed in aesthetics), but requires the recipient to be able to isolate it. Thus, as Bourriaud says, one cannot reduce form to the "thing" that the artist "produces", "is not the simple secondary $\mathrm{j}$ effects of a composition, as the formalistic aesthetic would like to advance, but the principle acting as a trajectory evolving through signs, objects, forms, gestures..."7. Consequently, it is not the "material form" but "a linking element, a principle of dynamic agglutination." that should be regarded as a form.

These reflections lay the grounds for the most important decision from the point of view of relational aesthetics, which consists in expanding the notion of "form" with the "element of dialogue". Bourriaud describes this variety of form as a "relational form". It is no longer what is given, what is intended for acts
Ibid.
Ibid.
Ibidem, p. 20.
Ibid. 
of perception. People cease to be treated as external spectators, without whose participation it can exist while waiting to be seen. Taking into account contemporary artistic practices, the French author argues that it would be better to talk about "formations" rather than "forms". "Unlike an object that is closed in on itself by the intervention of a style and a signature, present-day art shows that form only exists in the encounter and in the dynamic relationship enjoyed by an artistic proposition with other formations, artistic or otherwise." ${ }^{8}$. Therefore, form is not something constant, unchangeable, but living, developing in the process of interaction. What used to be not considered a form, nowadays becomes one ${ }^{9}$. In this context, Bourriaud cites the novel by Witold Gombrowicz, where all individuals create their own form through behavior and the way they present themselves to others and address them. This concept is important to him because the form is not given here, but created, and secondly because it refers to people, their way of being. He also refers to Sartre's concept of the gaze of the Other. Taking into account how other people perceive us, we can realize that the set of beliefs concerning ourselves that we considered objective differs from how they perceive and evaluate us. The question of form turns out to be far more complex than in traditional aesthetics. What we are dealing with is not the creation and reception (right or wrong), but the continuous formation and play of forms. Thus, it cannot be unambiguated by linking it to specific features of a work of art. Bourriad writes: "Our persuasion, conversely, is that form only assumes its texture (and only acquires a real existence) when it introduces human interactions. The form of an artwork issues from a negotiation with the intelligible, which is bequeathed to us. Through it, the artist embarks upon a dialogue. The artistic practice thus resides in the invention of relations between consciousness. Each particular artwork is a proposal to live in a shared world, and the work of every artist is a bundle of relations with the world, giving rise to other relations, and so on and so forth, ad infinitum...”. ${ }^{10}$

Thus, one cannot consider the form in a static, supra-historical way, absolutizing it in the sense that it is separated from activities of people - including the recipients. In the 1960s, the concept of Umberto Eco's "open work" clearly activated recipients in relation to the form of a work of art. Some analogies between his theory and relational aesthetics were noticed ${ }^{11}$. However, I believe that these analogies are only partial. First of all, Eco understands the form of a work of art in an essentially traditional way, in some respects only suggesting

8 Ibidem, p. 50.

9 As an example Bourriaud cites informel painting, which is currently not considered to be "formless". On the contrary, its shapes can be imitated, as evidenced by some of Roy Lichtenstein's works, such as Little Big Painting (1965).

10 N. Bourriaud, op. cit., p. 21.

11 An example is the article by Claire Bishop (op. cit., pp. 173-174). 
that the principles of its reception be made less strict. For him, form is associated with the artist's work, it is the form of a work understood as an object. The change that the Italian aesthetician introduced (inspired by the artistic trends that emerged in the 1960s and sometimes earlier) is to take into account a certain degree of openness of its limits. This openness was manifested in offering the viewer a real opportunity for to "manipulate" the elements of the work. It could consist in a search for different orders and systems in the complexity and ambiguity of the work. In particular, however, the activation of the viewer took place in the case of "works in motion". Performers of musical works (e.g. Luciano Berio or Pierre Boulez) or viewers watching e.g. Alexander Calder's Mobiles had to manipulate the form of the works. The musicians chose certain fragments from the score they played and skipped others. The viewers of the sculptures set in motion some elements of suspended constructions. Eco noted, however, that these actions are not entirely arbitrary, independent of the author's intentions concretized in the form of works of art. He emphasized that an open work "even before becoming a field of actualizable choices" of an artist or a recipient is "is already a field of actualized choices" 12 . Therefore, "only after his sensibility has been thus directed does he feel ready to move on to unchecked associations prompted by the presence of signs which, however free and casual, are nevertheless the products of an intention and, therefore, the marks of a work of art." ${ }^{13}$. The artist who creates a "work in motion" defines the form in such a way that it makes the activity of the viewer possible, and even provokes it. The role of the form is therefore determining, it is supposed to induce the viewer to perform certain activities. In this respect, its role is therefore no different from that of the closed form, although it acts in the opposite direction. The latter creates prohibitions and restrictions, while the former is meant to offer the freedom of association, making choices, physical activation, etc. In both cases, as Eco emphasizes, artist's expertise is indispensable, elements of "exercise" and "practice", which will allow him/her to implement the intended type of form. Therefore, the artist has control over his work and is its "owner". Thus, recipients' responses of are in a sense controlled by him/her - not in the sense of determining what should be done, but whether and to what extent creativity and activity should be liberated. Therefore, Eco writes that the creator of an open work does not know exactly how it will be completed by the viewer, is not able to predict all possible forms that it will take when interacting with the viewer, but "he is aware that once completed the work in question will still be his own. It will not be a different work, and, at the end of the interpretative dialogue, a form which is his form will have been organized, even though it may 
have been assembled by an outside party in a particular way that he could not have foreseen" ${ }^{14}$. The artist is also the recipient of his/her work and in a certain way concretizes it for his/her own use. The form of an open work makes this concretization only one of many possibilities.

Is the concept of form in relational art similar? Let us consider a number of examples of works by artists whose achievements Bourriaud takes into account in his concept. "A metal gondola encloses a gas ring that is lit, keeping a large bowl of water on the boil. Camping gears is scattered around the gondola in no particular order. Stacked against the wall are cardboard boxes, most of them open, containing dehydrated Chinese soups which visitors are free to add the boiling water to and eat"15. Regarding this work by Rirkrit Tiravanija, made during Aperto 93 at the Venice Biennale, the French author asks a question: is it a sculpture, an installation, a performance, or maybe socially engaged art? Is it possible, and is it worthwhile, to determine the genre of this project? Is what the artist brought to the gallery and arranged in a specific way supposed to determine the behavior of the audience through its form? If so, it is, I think, in a very general way. One can try some soup or sit in the corner of the room and start a conversation. Each of these acts is a kind of participation in Tiravanija's art, because it is associated with being together. As Bourriaud writes, relational artists propose "moments of sociability" and "objects producing sociability" 16 . Do these objects form this community, impose its character? In another work by Tiravanija a table is set on which ready meals are placed. Does it stimulate participants to behave differently, more ceremonially? The available documentation of the actual course of the action shows that the participants were as free as during Aperto 93. The point is not, therefore, to provoke certain reception behaviors by choosing the right form. The way participants behave is not meant to be determined by the form created by the artist, but to complement it by coshaping the work of art.

Another example is the work of Felix Gonzalez-Torres Untitled (Republican Years), shown by the Sprengel Museum in Hannover in 1992. It consisted of large sheets of paper stacked in a pile, on which double borders were printed using offset technology. This work, as Thomas Deecke writes, resembled the works of American minimalists because of the geometric, rectangular shape of both the sheets and the cuboid they formed. Another feature that encourages associations with that trend is the anonymity of the work and the fact that it is made by someone else according to the artist's instructions. However, while the sculptures by Donald Judd or Robert Morris were self-sufficient, unchangeable

14 Ibidem, p. 27.

15 N. Bourriaud, op. cit., p. 24.

16 Ibidem, p. 31. 
and self-referential, perfect in their material existence, Gonzalez-Torres "allows the viewers and even more so the users of the works to alter his sculptures up to the point when they seemingly disappear" ${ }^{17}$. At the exhibition, visitors could take sheets from the pile, so it changed proportions. The form proposed by the artist was therefore subject to permanent transformation. The viewers co-shaped it, but not in the same way as in the case of Calder's Mobiles, where after moving the system of hanging parts, a return to its original state took place. The sculpture by Gonzalez-Torres disappeared from the gallery, but at the same time it still existed in the form of single copies of prints in the viewers' homes. Therefore, Deecke writes about "the paradox of its double existence" 18 . Only a memory or photographic documentation remained of its original form. While the presence of the work and the place were also important for the minimalists, here it is the place and experience that are important. The activities of the recipients become a part of the form-making activities.

Liam Gillick is an artist who creates material artistic arrangements, which, however, are only a part of the structures of works of art. Drawing on to the ideas of International Situationalism, he claims that the basis of artistic activity is permission to create one's own situations. That is why his art is composed of "instruments of real space", people and emerging discussions. The first element is the places transformed by the artist by means of geometric plastic components, such as rectangular planes of plastic or aluminum suspended or glued directly on the gallery walls, redefined by means of light, sometimes enriched with scattered glossy dust. However, it is not the visual effects that are at stake here, but the creation of "Discussion Islands" - as Gillick puts it which are intended to provide a context for the exchange of ideas, to become centers of reflection. "The "disco strategy" based on the use of bright colors and reflective materials is supposed to foster communication because it is in disco clubs that modern people easily make contacts ${ }^{19}$. The artist also directly creates proposals for discussion by hanging texts and photographs on the walls. The point is to turn the "white cube" of the gallery, a traditional place of lonely contemplation of works of art, into a "think tank", where out of control, outside of a fixed script, sequences of options may be considered. "Recent projects," Gillick wrote about his work, "articulate a blurred relationships between people and effects in order to attempt an understanding of how concepts of the future have developed and are controlled within a post utopian context. The work is

17 T. Deecke, Felix Gonzalez-Torres (1957-1996), in: MINIMAL MAXIMAL. Die Minimal Art und ihr Einfluß auf die internationale Kunst der 90er Jahre, Neues Museum Weserburg, Bremen und Verlag Umschau/Braus, Bremen 1998, p. 121.

Ibidem, p. 121.

19 Cf. H. Helfert, R. Stange, Liam Gillick (1964), in: ibidem, p. 114. 
a negotiation of the way the future is continually re-thought via the proposal of a series of environmental tools. The creation of a number of images and objects that all deal with fundamental processes that are at the centre of social, economic and political activity - for example - negotiation, compromise, arbitration, bureaucracy, strategy and resignation" 20 .

Taking into account the above declaration, it is easy to understand the artist's oft-repeated belief that without people, what he presents is not art. It is only when the visitors to the exhibition take up the proposed topics that the form of the work is completed. "Provisional constructions", as Gillick describes his exhibitions, become spaces for "reassessment" and the work will not be a conclusion, but a material for discussion.

I have discussed in detail three examples of artistic activities classified by Bourriaud as relational art, as they allow us to become more aware of the nature and role of the notion of form, which he considers important. In all these examples, as well as in other creative achievements taken into account by the French author, the artist proposes certain elements of the work. These can be material objects, human beings (e.g. in Vanessa Beecroft's works) or activities in specific arrangements. However, they are not the full form of the work. They are not what, according to Eco's concept, would involve the viewer, induce $\mathrm{him} /$ her to take actions that would be active reception. What the artist does, what constitutes a controlled part of his formal activity, must be complemented by the activities of the participants and completed as part of the work, and not as an act of reception. People who prepare soup as part of Tiravanija's works are not recipients but co-creators of the form of the work. The same applies to those who take home posters arranged in a cubic heap by Gonzalez-Torres. They do not respond to the created form of an open work, but they co-create this form. Gillick put it clearly, stating: "My work is like the light in the fridge. It only works when there are people to open the fridge door. Without people, it's not art - it's something else - it's stuff in the room" ${ }^{21}$. For Eco, Calder's sculptures were works of art, "works in motion", while for Gillick, his objects and installations are only objects that become an artistic form once people appear and start to perform certain activities.

This dual, relation-based concept of form, however, poses the danger of considering only one of its aspects (e.g. objective) and treating it as an object intended for traditional contemplative reception. Bourriaud did not want to see this difficulty. He accused Bishop of "looking for cracks" between "conceptual and sculptural activity" and "social cooperation" in drawing attention to it. $\mathrm{He}$

20 L. Gillick, Big Conference Platform Platform, 1998, in: ibidem, p. 115.

21 L. Gillick, Renovation Filter: Recent Past and Near Future, exhibition catalogue. 
wrote: "Artists discussed in Relative Aesthetics abolish the opposition between the 'ethical' - external to form - and the aesthetic aspect of a work of art. This crack turns out to be the result of a false premise, and the choice between sociopolitical involvement and artistic creation is unfeasible. This is what determines the originality and aesthetic strength of relational art" 22 . However, other authors dealing with the issue of participation in art were of a different opinion. They believed that due to the new situation of the artistic sphere, the approach to aesthetics and values it emphasizes should also be modified.

Grant Kester, author of the concept of dialogical aesthetics, believes that "writing in the shadow" of current events (including the terrorist attack of 11 September and its repercussions, cultural, religious and national conflicts, the market system that becomes the framework for contacts also in the field of cultural goods) makes particularly important creativity that is focused not so much on the production of artistic objects as on seeking contacts. Kester also points out that "There are, however, a number of contemporary artists and art collectives that have defined their practice around the facilitation of dialogue among diverse communities. Parting from the traditions of object-making, these artists have adopted a performative, process-based approach ${ }^{23}$. It is with their activity that hopes for future resolution of social conflicts and a new definition of the place of art in society. Therefore, aesthetics, which has been concentrating on issues related to the subject matter of art, should turn to the problem of aesthetic experience by modifying it accordingly. The approach to this problem has so far been dominated by the role attributed to the perception of works of art and the interpretation of their meaning. At present, it is relations between the participants of the aesthetic experience that are essential. They are to take the form of a dialogue not with the work or the artist hidden behind it, but with human subjects present at the same time in a specific place.

Kester is critical of both modernist and postmodern concepts of aesthetic experience, which, in his opinion, were based on a peculiar "correction" of the audience. These experiences were meant to lead them outside the world of everyday matters that people usually live in, as well as outside the issues addressed in social discourses. This position is described by the American author as "orthopedic" aesthetics. He posits that in "orthopedic" aesthetics the viewer is treated as imperfect by nature and therefore his/her perception apparatus needs to

22 N. Bourriaud, "Szlakiem teoretycznym od relacyjnego do 'wędrującego'. Wstęp do wydania polskiego" [Theoretical path from the relational to the 'wandering'. Foreward to the Polish edition], Estetyka relacyjna [Relational Aesthetics], transl. Ł. Białkowski, MOCAK. Muzeum Sztuki Współczesnej w Krakowie, Kraków 2012, p. 20. 
be corrected. This proposition assumed that art and aesthetics are able to lead people beyond the common sense cognitive orientation shaped and sustained by the hegemonic cultural system. Nowadays, it is disseminated by the mass media and journalism, which are controlled by political ideologies. Within this system, an important role is attributed to the artist. In aesthetic concepts he/ she is presented implicitly, if not explicitly, as a higher being, capable of penetrating the veil of mystification to which ordinary art viewers succumb. Often, especially since the twentieth-century Avant-Garde (if not Romanticism), he/ she has been credited with special cognitive abilities, in that he/she is not only able to truly recognize the situation of humanity but also to find remedies. "This belief" writes Kester, "that the viewer suffers from an epistemological lack that will be corrected by the artist brings the orthopedic aesthetic into surprising proximity to the rhetoric of advertising, which promises viewers access to a more prestigious or enlightened social identity if they engage in the requisite act of consumption" ${ }^{24}$. Similarly as in the case of advertising, there is no point in waiting for such an ideal recipient to be shaped but he/she is rather actively shaped through "corrective" treatments.

The concept of dialogical aesthetics assumes a different model, based on the experience of participation. The artist does not impose his/her vision on the audience there but enters into consultations with them, the expression of which is a joint work. However, it is not the central point of the aesthetic situation. It is not so much the objective of action as the result of a situation based on mutual understanding and exchange of views. Kester believes that major steps in this direction were taken in the 1990s, although he notes certain signs heralding this shift as far back as the 1960s and 1970s. He often cites the activity of the Austrian art collective Wochenklausur as an example. As part of one of their actions, held in 1994, they organized a three-hour meeting on a small cruise boat, during which the difficult situation of old prostitutes, often drug addicts and the homeless, was discussed. Addressing this topic, which provokes averse or aggressive response in people from different backgrounds, indicated an interest in a significant social problem, and, moreover, showed ethical sensitivity. The meeting was attended by people of different professions, from various walks of life, interested in this subject because of their profession and guided by compassion for other human beings. Twelve such "floating dialogues" on various topics were organized over a long time, involving some sixty people, including the most important figures in Zurich public life.

Kester believes that the concept of dialogical art combines ethics, performance and participation. The first element, however, seems to be the most

24 G. Kester, Conversation Pieces: Community and Communication in Modern Art, University of California Press, Berkeley 2004, p. 88. 
important, as the concepts of performance and participation are transformed due to the ethical perspective from which they are approached. This perspective, however, concerns not only topics addressed in this art, but also refers to aesthetic issues. As the American author emphasizes, the "simple opposition between object (or image) and action, or between 'passive' viewers and 'active' participants" 25 , which introduced inequality in aesthetic situations and contributed to "corrective actions", is abolished. Instead there is an "inter-subjective exchange". It has an ethical dimension but the American author defends himself against accusations that aesthetic criteria are replaced by ethical ones in analyses of participatory practice. "Aesthetics," he writes, "has, of course, always carried an explicitly ethical meaning. What is changing now is the specific relationship between ethics and aesthetics in this work" ${ }^{26}$

Claire Bishop is critical of the concept of ethical criteria as norms for evaluating participatory art. Even assuming, as Kester claims, that dialogue art imposes the need to change the understanding of what art in general is (by limiting sensory themes as individual) and focus on exchange of views and negotiations, the English author considers the proposal of a far-reaching approximation of aesthetics and ethics to be wrong. She considers two examples of dialogical activities that were analyzed in Conversation Pieces, but which lead to the results in question. In the first case, it is a concrete sculpture House (1993) cast by Rachel Whiteread and based the interior of a demolished terrace, referring to the specific conditions of the Bow district. The second one is a billboard project Loraine Leeson West Meets East (1992) made in cooperation with students of Bengali origin living in the UK. It addresses their specific life problems. In both cases, the aim is to learn and show the truth about cultural and political contexts related to the place and history of specific people, their particular needs and identity. Kester, as Bishop points out, showed aversion to dealing with the form of both works and the affective reactions they provoked, but highly valued the emphatic identification which, in his opinion, allows us to go beyond our own experiences and establish relationships with others based on compassion. At the same time, the author points to an ethical contradiction in this concept. Kester, acting in accordance with the spirit of human rights and identity policy with respect to co-participants in artistic activities and their audiences, at the same time restricts the rights of artists. The English author writes: "In insisting upon consensual dialogue, sensitivity to difference risks becoming a new kind of repressive norm - one in which artistic strategies of di-

25 G. Kester, Galatea's Gaze: Ethics, Spectacle, and Participation, https://pl.scribd.com/document/212072766/Grant-Kester-Galatea-s-Gaze-Ethics-Spectacle-and-Participation (access: 12 March 2018).

Ibidem. 
sruption, intervention or over-identification are immediately ruled out as 'unethical' because all forms of authorship are equated with authority and indicted as totalising. Such a denigration of authorship allows simplistic oppositions to remain in place: active versus passive viewer, egotistical versus collaborative artist, privileged versus needy community, aesthetic complexity versus simple expression, cold autonomy versus convivial community" 27 . Idiosyncratic and controversial ideas are therefore repressed, suppressed and normalized in favor of consensual behavior.

As regards participatory art, Bishop sees the need for a different change in aesthetics. She links it to the influence of Jacques Rancière's concept. Although he did not write about participatory art, the consequences of his views allow us to approach the issues raised here from a different perspective. The French philosopher claimed that the art system, which he calls the "aesthetic regime of art", is based on the tension between autonomy (which distinguishes art from a purely practical area, based on the principle of measure and purpose) and heteronomy, where the line between what is artistic and what is life-related is blurred. The paradox associated with this situation (derived by Rancière from Schiller's views) is that there is no clear boundary here, and something is art to the extent that it is something other than art. However, the French author associates the concept of autonomy not to works of art, but to the experience that appears in relation to art. He believes that the inconclusive nature of aesthetic experience calls into question the way in which the world is organized. This opens the way to politics, understood by him as disagreement, and therefore questions about the possibility of changing and redistributing the world. Rancière calls this "sharing the sensible". In this area, aesthetics and politics overlap where ideas, experiences and skills are concerned. This sharing can be done in both a progressive and a reactionary sense. Therefore, as Bishop writes, "In this framework, it is not possible to conceive of an aesthetic judgement that is not at the same time a political judgement" 28 .

These views are used by the English author in the presentation of her position, polemical on the one hand towards the concept of relational aesthetics, and on the other - dialogical aesthetics. With regard to the latter concept, she questions what is called the "ethical turn" due to, as Rancière put it, the combination of the quest for consensus and the principle of infinite injustice. The elimination of the conflict that both Bourriaud and Kester assumed to be related to issues of inclusion and exclusion replaces the political problems

27 C. Bishop, Artificial Hell. Participatory art and audience politics, Verso, London-New York 2012, p. 25.

28 Ibidem 27. I am presenting Rancière's views the way Bishop presents them because her distribution of accents is important. 
inherent in aesthetics with the slogans of "disappearance of social bond", i.e. generally understood issues of a person considered in an abstract way. Politics and aesthetics then disappear into ethics. "For to Rancière," Bishop writes, "the ethical turn does not, strictly speaking, denote the submission of art and politics to moral judgements, but rather the collapse of artistic and political dissensus in new forms of consensual order" 29 . Both in politics, where "infinite evil" is distinguished from "infinite justice", and in art and aesthetics, where "discriminating" and "corrective" actions of avant-garde artists are opposed to the concepts of harmonious coexistence and cooperation in artistic community projects, the political and aesthetic dimension is blurred. Rancičre's important contribution to the contemporary debate on art and politics was therefore, according to Bishop, "to reinvent the term 'aesthetics" so that it denotes a certain type of experience. "In this logic," writes the English author, "all claims to be 'anti-aesthetic' or reject art still function within the aesthetic regime. The aesthetic for Rancière therefore signals an ability to think contradiction: the productive contradiction of art's relationship to social change, which is characterised by the paradox of belief in art's autonomy and in it being inextricably bound to the promise of a better world to come. While this antinomy is apparent in many avant-garde practices of the last century, it seems particularly pertinent to analysing participatory art and the legiti- mating narratives it has attracted. In short, the aesthetic doesn't need to be sacrificed at the altar of social change, because it always already contains this ameliorative promise." 30

The reference to Rancière's concept of aesthetics seems to provide Bishop with arguments, especially in the polemic with the aesthetic assumptions of Kester and other authors advocating the "ethical turn". The idea of relational aesthetics seems to be combined with a positive attitude towards the avant-garde tradition. While Bourriaud emphasized formal transformations, modifying the concept of form taking into account the works of artists from the 1990s, the American author refers to the actionist trend, examining it from Futurism and Dadaism to happenings. Thus, she attributes a more significant role to artistic activities that enter more directly into the area of social life, questioning the role of the components in art. She accuses Bourriaud of not specifying the concept of relations, which is crucial for his theory. "Bourriaud", she writes: "to equate aesthetic judgment with an ethicopolitical judgment of the relationships produced by a work of art. But how do we measure or compare these relationships?" 31 . She also accuses the French critic that, when writing about democracy, he does not ask what type of democracy he has in mind. She her-

29 Ibidem, p. 28.

30 Ibidem, pp. 59-60.

31 C. Bishop, Antagonism and Relational Aesthetics, OCTOBER, 110, Fall 2004, p. 65. 
self, referring to the views of Ernesto Laclau and Chantal Mouffe expressed in the book Hegemony and Socialist Strategy: Towards a Radical Democratic Politics (1985), advocates the concept of antagonism. The authors of this book prove that a democratic society is not about the disappearance of antagonisms, and that its political boundaries are constantly being redefined and debated. Otherwise, the imposed order is authoritarian in nature. These assumptions apply to participatory art. She believes that it is most interesting when "Instead of extracting art from the 'useless' domain of the aesthetic and fusing it with social praxis, the most interesting art today exists between two vanishing points: 'art becoming mere life or art becoming mere art"' 32 .

Concepts of relational, dialogical and participatory aesthetics are developed in close connection with art. In this respect, they differ from what Wolfgang Welsch described as "aesthetics beyond aesthetics", and, more specifically, beyond the philosophy of art. In the mid-1990s, he proposed to overcome the "traditional" stereotype and embrace a broader understanding of the discipline of "aesthetics" 33 . Among the arguments in favor of such an expansion, he pointed out the need to address the phenomena of "fashioning of reality"- widespread in the contemporary world - through its embellishment, as well as "understanding of reality", in which the aesthetic approach is manifested in the epistemological and ethical sphere. These concepts, e.g. in Poland, have had a significant impact on those in the field of aesthetics. The issues discussed in this article stem from the conviction that art as a source of aesthetic reflection is still inspiring, and aesthetics derived from the reflection on art is not only one of the great narratives of Modernism coming to an end. The concepts discussed here certainly do not resolve the dilemmas that have led to the recognition that aesthetics is in a state of crisis. However, they allow us to notice its renewed connection with the artistic sphere, understood in a broader sense and to a significantly different degree. The essence of this new character of aesthetics is well reflected in the title of Grant Kester's article, The Vicissitudes of the Aesthetic ${ }^{34}$. The aesthetic shifts also within the art itself. Aesthetics, therefore, can open up to new ways of understanding the relationship between creativity and reception, new concepts of a work, new places and an artist, etc. The aesthetics can also open up to new ways of understanding the relationship

32 C. Bishop, The Social Turn: Collaboration and Its Discontents, https://artasprocessfa/2011/. files.wordpress.com/2011/09/claire-bishop-the social-turn-collaboration-and-its-discontents. pdf (access: 15 July 2018). The article was published in "Art International" in 2006).

33 Cf. W. Welsch, Aesthetics Beyond Aesthetics, Proceedings of the XIII International Congress of Aesthetics, Lahti 1995, Vol. III: Practical Aesthetics in Practice and Theory, ed. Martti Honkanen, Helsinki 1997.

34 G. Kester, The Vicissitudes of the Aesthetic, https://www.academia.edu/5329612/The_Vicissitudes_of_the_Aesthetic_2012 (access: 10.08.2018). 
between creativity and reception, new concepts of a work of art, place and artist, etc. Kester writes that many beliefs about value and aesthetic "categories and terms" must change as a result.

\section{BIBLIOGRAPHY}

Bishop C. (2004), Antagonism and Relational Aesthetics, OCTOBER, 110, Fall.

Bishop C., The Social Turn: Collaboration and Its Discontents, https://artasprocessfa/2011/.files. wordpress.com/2011/09/claire-bishop-the social-turn-collaboration-and-its-discontents.pdf (access: 15 July 2018). The article was published in "Art International" in 2006)

Bishop C. (2012) Artificial Hells Participatory Art and the Politics of Spectatorship, London, Ney York: Verso.

Bishop C. (2004), Antagonism and Relational Aesthetics, "October”, No 110; reprint: (ed. Z Kocur and S. Leung), Theory in Contemporary Art Since 1985, II ed., 2013, Malden - Oxford: WileyBlackwell.

Bourriaud Nicolas (2002) Relational Aesthetics, transl. Simon Pleasance and Fronza Woods with M. Copeland, Dijon: Les presses du réel.

Deecke T. (1998) Felix Gonzalez-Torres (1957-1996), in: MINIMAL MAXIMAL. Die Minimal Art und ihr Einfluß auf die internationale Kunst der 90er Jahre, Neues Museum Weserburg, Bremen: Bremen und Verlag Umschau/Braus.

Eco U. (1989), Open Work, transl. J Anna Cancogni, Harvard University Press.

Kester G. (2004) Conversation Pieces: Community and Communication in Modern Art, Berkeley: University of California Press.

Kester, G., Galatea's Gaze:Ethics, Spectacle, and Participation, https://pl.scribd.com/document/212072766/Grant-Kester-Galatea-s-Gaze-Ethics-Spectacle-and-Participation (access: 12 March 2018).

Kester G., The Vicissitudes of the Aesthetic, https://www.academia.edu/5329612/The_Vicissitudes_of_the_Aesthetic_2012 (access: 10.08.2018)

Welsch W. (1997), Aesthetics Beyond Aesthetics, Proceedings of the XIII International Congress of Aesthetics, Lahti 1995, Vol. III: Practical Aesthetics in Practice and Theory, ed. Martti Honkanen, Helsinki. 


\section{SZTUKA, PARTYCYPACJA, ESTETYKA (streszczenie)}

Autorzy głównych koncepcji łączących sztukę z problematyką partycypacji używają w odniesieniu do swych teorii nazwy „estetyka”. Celem artykułu jest rozważenie, pod jakimi względami autorzy ci nawiązują do tradycyjnej problematyki estetycznej oraz jakim modyfikacjom ją poddają. Rozważania skoncentrowane są na trzech koncepcjach. W estetyce relacyjnej Nicolasa Bourriauda istotną rolę pełni pojęcie „formy” zmodyfikowane w taki sposób, żeby objąć nim stosunki międzyludzkie pojawiające się w związku z sytuacjami artystycznymi. W ten sposób odbiorcy i ich zachowania stają się częścią dzieł sztuki. W artykule zagadnienie to skonfrontowane jest z teorią „dzieła otwartego" Umberta Eco. Omówione są też, jako przykłady sztuki relacyjnej, wybrane dokonania Rirkrita Tiravanji, Felixa Gonazaleza-Torresa i Liama Gillicka. Estetyka dialogiczna Granta Kestera przedstawiona została jako przykład powiązania sztuki z partycypacją, w którym na pierwszy plan wysuwane jest doświadczenie i dominują wartości etyczne. Natomiast Claire Bishop uważa, że sztuka partycypacyjna prowadzi do konieczności daleko idących zmian w pojmowaniu estetyki. Nawiązując do koncepcji filozoficznej Jacquesa Rancièra twierdzi, że nierozstrzygalność doświadczenia estetycznego pociąga za sobą konieczność zakwestionowania sposobu zorganizowania świata. W związku z tym następujące w sztuce partycypacyjnej „dzielenie postrzegalnego” jest jednocześnie osądem politycznym. Angielska autorka akcentuje też nie harmonizację relacji międzyludzkich (zakładaną w estetyce relacyjnej), a antagonizm pozwalający wciąż na nowo zarysowywać i czynić przedmiotem debat problemy społeczne. Artykuł zamyka pytanie o to, czy estetyka relacyjna, dialogiczna i partycypacyjna otwiera nowe pole dla uprawiania refleksji estetycznej nadbudowywanej nad zjawiskami artystycznymi.

Słowa kluczowe: estetyka relacyjna, estetyka dialogiczna, estetyka partycypacyjna, wspólczesna estetyka a refleksja nad sztuką 